\title{
Pengaruh Konsentrasi dan Lama Perendaman Air Perasan Daun Pegagan terhadap Kualitas Daging Babi Ditinjau dari Uji Organoleptik
}

\author{
(THE EFFECT OF CONCENTRATION AND LENGTH OF PEGAGAN LEAF SOAKING \\ AGAINST THE QUALITY OF PORK MEATREVIEWED FROM ORGANOLEPTIC TESTS)
}

\author{
Putu Henrywaesa Sudipa ${ }^{1 *}$, Ida Bagus Ngurah Swacita², I Made Sukada ${ }^{2}$, \\ Luh Made Sudimartini ${ }^{3}$, Kadek Karang Agustina ${ }^{2}$ \\ ${ }^{1}$ Laboratorium Bakteri dan Mikologi Veteriner, Fakultas Kedokteran Hewan, \\ Universitas Udayana, Jln. PB. Sudirman Denpasar, Bali; \\ ${ }^{2}$ Laboratorium Kesehatan Masyarakat Veteriner, Fakultas Kedokteran Hewan, Universitas \\ Udayana, Jln. PB. Sudirman Denpasar, Bali; \\ ${ }^{3}$ Laboratorium Farmasi, Fakultas Kedokteran Hewan, Universitas Udayana Jln. PB. Sudirman \\ Denpasar Bali. \\ *Email: henrywaesa@unud.ac.id
}

\begin{abstract}
Abstrak
Hampir semua daging di pasar tercemar oleh mikroorganisme. Akibat kontaminasi mikroorganisme tersebut maka dapat terjadi perubahan warna, bau, dan konsistensi. Penelitian ini bertujuan untuk mempelajari pengaruh berbagai tingkatan konsentrasi dan lama perendaman air perasan daun Pegagan (Centella asiatica L.) serta mempelajari ada tidaknya interaksi antara konsentrasi dan lama perendaman air perasan daun pegagan (Centella asiatica L.) terhadap kualitas daging babi ditinjau dari uji organoleptik. Perendaman daging babi di dalam air perasan daun pegagan dilakukan dengan memasukkan masing-masing potong daging ke dalam 8 gelas beker yang telah berisi kontrol, konsentrasi air perasan daun pegagan $5 \%, 10 \%$, dan $15 \%$. Perendaman dilakukan selama 5 menit dan 10 menit kemudian daging ditiriskan selama 15 menit, kemudian dilakukan uji organoleptik dan dianalisis dengan sidik ragam. Hasilnya konsentrasi berpengaruh nyata $(\mathrm{P}<0,05)$ terhadap perubahan warna, bau dan konsistensi daging. Sedangkan lama perendaman berpengaruh nyata $(\mathrm{P}<0,05)$ terhadap bau daging namun tidak berpengaruh tidak nyata $(\mathrm{P}>0,05)$ pada warna dan konsistensi daging babi. Dan juga tidak terdapat interaksi antara konsentrasi dan lama perendaman.
\end{abstract}

Kata kunci: Daging babi; air perasan daun pegagan (Centella asiatica L.); uji organoleptik.

\begin{abstract}
Almost all meat on the market is contaminated by microorganisms. As a result of the contamination of microorganisms, it changes in color, odor, and consistency. This research aims to study the effect of various levels of concentration and soaking time of Pegagan (Centella asiatica L.) leaf juice and to study whether there is an interaction between concentration and soaking time of Centella asiatica L. juice on the quality of pork in terms of the organoleptic test. Soaking pork in the juice of Centella asiatica $L$. juice is done by inserting each piece of meat into eight glasses, which have been filled with control, $5 \%, 10 \%$, and $15 \%$ concentration juice. Soaking is done for 5 minutes, and 10 minutes then the meat is drained for 15 minutes, then an organoleptic test is performed and analyzed by variance. The results of the concentration had a significant effect $(\mathrm{P}<0.05)$ on changes in color, odor, and consistency of meat. While the soaking time had a significant effect $(\mathrm{P}<0.05)$ on the smell of meat but no significant effect $(\mathrm{P}>0.05)$ on the color and consistency of pork. And also, there is no interaction between concentration and soaking time.
\end{abstract}

Keywords: Pork; Centella asiatica L; leaf juice; organoleptic test. 


\section{PENDAHULUAN}

Daging di pasar jarang sekali berada dalam keadaan steril, hampir semua daging di pasar tercemar oleh mikroorganisme, ditambah lagi dalam proses penyimpanan daging tersebut juga tidak lepas dari kontaminasi mikroorganisme. Akibat kontaminasi mikroorganisme tersebut maka dapat juga mempengaruhi penampilan fisik daging tersebut antara lain terjadi perubahan warna, bau, dan konsistensi (Suada et al., 2018). Ditambah lagi makin maraknya penggunaan pengawet kimia formalin pada daging segar akhir-akhir ini yang membahayakan kesehatan konsumen. Pengawet tersebut digunakan untuk mencegah terjadinya pembusukan oleh bakteri patogen pada bahan pangan terutama yang berkadar air dan gizi tinggi seperti daging. Maka diperlukan suatu bahan alami yang aman dipakai untuk menurunkan cemaran bakteri tersebut (Nowshad et al., 2018).

Daging yang umum dikonsumsi dan dipasarkan di Indonesia adalah daging sapi, domba, kambing, babi, ayam, itik, ikan dan lainnya, khususnya di Bali sebagian besar masyarakat Bali mengonsumsi daging babi dibandingkan daging ternak lainya (Agustina et al., 2016). Di Bali beberapa ternak babi yang dagingnya umum dikonsumsi dan beredar dipasaran adalah babi bali dan babi landrace, kedua ternak babi tersebut berasal dari bangsa yang berbeda dan pada umumnya melalui manajemen pemeliharaan yang berbeda. Babi bali merupakan babi tipe lemak dan dipelihara secara tradisional dengan pakan bernutrisi rendah seperti: dedaunan dan limbah dapur (Budaarsa et al., 2013).

Manusia mengkonsumsi daging sejak dimulainya sejarah peradaban manusia itu sendiri. Seiring dengan perkembangan zaman, maka daya beli konsumen terhadap daging selalu meningkat, sehingga tuntutan kuantitas akan beralih pada kualitas terhadap daging tersebut (Arka, 1990). Untuk memenuhi permintaan kualitas daging yang baik terutama terhadap cemaran mikroorganisme dapat digunakan penambahan bahan-bahan tradisional yang tidak memiliki efek samping, sehingga aman dikonsumsi (Agustina et al., 2017a), salah satunya adalah daun pegagan.

Daun pegagan memiliki nama latin Centella asiatica $L$, masyarakat secara tradisional memakainya untuk pengobatan (Azzahra dan Hayati, 2018). Bisa dikonsumsi dalam bentuk segar, diramu, dimasak, atau dijus. Pegagan biasa tumbuh pada tempat yang lembab, di sekitar pekarangan rumah atau di sepanjang tepi sungai. Tanaman daerah tropis ini berbunga sepanjang tahun. Bentuk daunnya bulat, batangnya lunak, beruas, dan menjalar hingga bisa mencapai semeter tingginya. Bagian yang sering dimanfaatkan adalah daunnya (Bermawie et al., 2008). Di antara sekian banyak kandungan bahan aktif pada pegagan seperti asam bebas, mineral, vitamin $\mathrm{B}$ dan $\mathrm{C}$, bahan utama yang dikandungnya adalah steroid, yaitu triterpenoid glycoside (Sutardi, 2016). Terdapat penelitian bahwa secara in vitro, infus dan ekstrak daun pegagan mempunyai daya antimikroba, khususnya terhadap Staphylococcus aureus (Nurrosyidah et al., 2019) dan Escherichia coli (Agfadila et al., 2017). Komponen bioaktif pegagan yang memiliki sifat antibakteri adalah flavonoid, tanin dan saponin (James, 2009). Penghambatan ekstrak pegagan terhadap bakteri telah dilakukan oleh Dash et al. (2011) yang menunjukkan bahwa ekstrak pegagan dapat menghambat bakteri Proteus vulgaris, Staphylococcus aureus, Bacillus subtilis dan Escherichia coli (Jagtap et al., 2009).

Senyawa aktif di atas akan sangat berpengaruh terhadap kualitas daging karena dapat menurunkan cemaran bakteri yang dapat juga mempengaruhi penampilan fisik daging yang dapat dinilai dengan uji organoleptik, jika diberikan dalam berbagai konsentrasi dan lama perendaman tertentu. Semakin tinggi konsentrasi, semakin banyak jumlah senyawa aktif yang terkandung dalam suatu larutan perasan daun pegagan. Diharapkan dengan konsentrasi yang semakin tinggi, maka 
semakin berpengaruh terhadap kualitas daging, sedangkan lama perendaman mempunyai arti lamanya waktu kontak antara daging dan senyawa aktif air perasan daun pegagan. Semakin lama direndam atau kontak dengan zat aktif, maka semakin berpengaruh terhadap kualitas daging babi tersebut. Selain itu perlu juga diketahui apakah konsentrasi dan lama perendaman air perasan daun pegagan memiliki interaksi satu sama lain dalam memberikan efek terhadap kualitas daging babi tersebut. Penelitian ini perlu dilakukan untuk mempelajari apakah air perasan daun pegagan dapat mempengaruhi kualitas daging babi ditinjau dari uji organoleptik.

\section{METODE PENELITIAN}

\section{Sampel}

Sampel yang digunakan dalam penelitian ini adalah daging babi yang dibeli di pasar sebanyak 250 gram, untuk satu kali penelitian, penelitian ini diulang sebanyak 4 kali, dengan interval waktu kurang lebih 1 minggu, jadi jumlah daging yang diperlukan sebanyak 250 gram x $4=$ 1000 gram atau $1 \mathrm{~kg}$. Kemudian daging dimasukkan ke dalam termos yang berisi es untuk kemudian dibawa ke laboratorium.

\section{Sterilisasi alat}

Alat- alat yang digunakan disterilkan dengan autoclave pada suhu $121^{\circ} \mathrm{C}$ dengan tekanan 15 P.S.I selama 15 menit, sedangkan untuk alat-alat yang tidak tahan panas didesinfeksi dengan menggunakan alkohol $70 \%$.

\section{Panelis}

Seluruh panelis adalah mahasiswa Fakultas Kedokteran Hewan, semester 9, berumur antara 22-24 tahun, sudah mengambil mata kuliah Kesmavet 1 dan 2, tidak memiliki cacat, sehat lahir dan batin.

\section{Perlakukan sampel}

Daging babi seberat 250 gram dibagi menjadi 8 potong dengan berat \pm 25 gram tiap potongan, dibentuk seperti kubus. Kemudian ke 8 potongan tadi dimasukkan ke dalam gelas beker, direndam dengan akuades selama 5 menit.

\section{Penentuan konsentrasi dan pembuatan air perasan daun pegagan}

Pembuatan air perasan daun pegagan dilakukan dengan menimbang 100 gram daun pegagan kemudian digerus dengan mortar sampai hancur lalu disaring. Air perasan tersebut kemudian diletakkan di dalam gelas beker. Konsentrasi air perasan daun pegagan terdiri atas 4 kategori yaitu kontrol $0 \%$ (tanpa air perasan daun pegagan, hanya $50 \mathrm{ml}$ akuades saja), konsentrasi $5 \%$ (1 $\mathrm{ml}$ air perasan daun pegagan ditambah $49 \mathrm{ml}$ akuades), konsentrasi $10 \%$ (5 ml air perasan daun pegagan ditambah $45 \mathrm{ml}$ akuades) dan konsentrasi $15 \%(7,5 \mathrm{ml}$ air perasan daun pegagan dan $42,5 \mathrm{ml}$ akuades).

\section{Penentuan bahan kering (BK) daun pegagan}

Pembuatan air perasan daun pegagan dapat dilakukan dengan menimbang \pm 10 gram daun pegagan, lalu dipotong kecilkecil kemudian digerus lalu dioven selama 5 jam yang dimaksud untuk menentukan bahan kering daun pegagan.

Prosedur penentuan bahan kering ( BK) daun pegagan adalah timbang berat cawan kosong (a), lalu timbang berat cawan kosong + daun pegagan yang telah digerus (b), dan timbang berat cawan + daun pegagan setelah dioven (c).

Berat awal $=(b-a)$

Berat akhir $=(\mathrm{c}-\mathrm{a})$, jadi BK dapat dihitung dengan rumus:

Kadar Air (\%)

$=\frac{\text { Berat Awal }- \text { Berat Akhir }}{\text { Berat Awal }} \times 100$

BK $(\%)=100 \%-$ Kadar Air $(\%)$

\section{Perendaman daging babi dalam air perasan daun pegagan}

Perendaman daging babi di dalam air perasan daun pegagan dilakukan dengan memasukkan masing-masing potong daging ke dalam 8 gelas beker yang telah berisi kontrol, konsentrasi air perasan daun pegagan $5 \%, 10 \%$, dan $15 \%$. Perendaman 
dilakukan selama 5 menit dan 10 menit kemudian daging ditiriskan selama 15 menit.

\section{Pengujian kualitas daging}

Pengujian kualitas daging dilakukan dengan uji organoleptik, dimana uji organoleptik ini dilakukan oleh 10 orang panelis dengan melakukan pemeriksaan terhadap kualitas daging, yang meliputi:

\section{Uji warna}

Ke dalam masing-masing gelas beker dimasukkan daging, kemudian diangkat dan pada latar putih diamati warnanya. Hasil pengamatan diberi skor $(1=$ warna menyimpang, 2 = warna normal yaitu putih sampai putih kekuningan).

\section{Uji bau}

Ke dalam masing-masing gelas beker dimasukkan daging, kemudian diletakkan pada piring kue dan dicium baunya. Hasil pengamatan diberi skor $(1=$ bau menyimpang, 2 = bau normal yaitu bau khas daging).

\section{Uji konsistensi}

Ke dalam masing-masing gelas beker dimasukkan daging, kemudian diletakkan dipiring kue. Kemudian permukaan daging ditekan untuk mengetahui konsistensi daging. Hasil pengamatan diberi skor $(1=$ konsistensi menyimpang, lembek atau sangat kenyal, $2=$ konsistensi normal daging atau kenyal).

\section{Rancangan penelitian}

Penelitian ini memakai Rancangan Acak Kelompok (RAK) pola faktorial 4x2 yaitu 4 konsentrasi yang berbeda dan 2 macam lama waktu perendaman yaitu 10 dan 20 menit, dengan Penelitian diulang sebanyak 4 kali. Sehingga jumlah sampel seluruhnya adalah $4 \times 2 \times 4=32$ unit percobaan.

\section{Analisis data}

Data uji organoleptik yang diperoleh dari 4 kali ulangan ditabulasi kemudian dirata-ratakan, lalu dijadikan persentase, selanjutnya dianalisis dengan sidik ragam dan dijelaskan secara deskriptif.

\section{HASIL DAN PEMBAHASAN}

Dari hasil yang tertera pada Tabel 1 menunjukkan bahwa rata-rata skor tingkat penerimaan uji organoleptik adalah uji warna pada konsentrasi $0 \%$ yang direndam selama 5 menit adalah $85 \%$, dengan tingkat penolakan $15 \%$, yang direndam selama 10 menit $92,5 \%$, tingkat penolakan $7,5 \%$, pada konsentrasi $5 \%$ yang direndam selama 5 menit adalah 90\%, dengan tingkat penolakan $10 \%$, yang direndam selama 10 menit adalah $85 \%$ dengan tingkat penolakan $15 \%$, pada konsentrasi $10 \%$ yang direndam selama 5 menit adalah $67,5 \%$, tingkat penolakannya $32,5 \%$ yang direndam selama 10 menit adalah 50\%, dengan tingkat penolakan 50\%, pada konsentrasi $15 \%$ yang direndam selama 5 menit adalah $70 \%$, tingkat penolakannya $30 \%$, yang direndam selama 10 menit adalah $40 \%$, dengan tingkat penolakan $60 \%$.

Sedangkan pada uji bau pada konsentrasi $0 \%$ yang direndam selama 5 menit tingkat penerimaannya adalah $85 \%$, dengan tingkat penolakan $15 \%$, yang direndam selama 10 menit $97,5 \%$, dengan tingkat penolakannya 2,5\%, pada konsentrasi $5 \%$ yang direndam selama 5 menit adalah $90 \%$, tingkat penolakannya $10 \%$, yang direndam selama 10 menit adalah $80 \%$, dengan tingkat penolakannya $20 \%$, pada konsentrasi $10 \%$ yang direndam selama 5 menit adalah $82,5 \%$, tingkat penolakannya $17,5 \%$, yang direndam selama 10 menit adalah 65\%, dengan tingkat penolakan $35 \%$ pada konsentrasi $15 \%$ yang direndam selama 5 menit adalah $77,5 \%$, tingkat penolakannya $22,5 \%$, yang direndam selama 10 menit adalah $65 \%$, dengan tingkat penolakan 35\%.

Kemudian pada uji konsistensi tingkat penerimaannya adalah: pada konsentrasi $0 \%$ yang direndam selama 5 menit adalah $100 \%$, yang direndam selama 10 menit $97,5 \%$, dengan tingkat penolakan 2,5\%, pada konsentrasi $5 \%$ yang direndam selama 5 menit adalah 90\%, dengan tingkat 
penolakannya $10 \%$, yang direndam selama 10 menit adalah 97,5\%, tingkat penolakannya $2,5 \%$, pada konsentrasi $10 \%$ yang direndam selama 5 menit adalah $92,5 \%$, dengan tingkat penolakannya $7,5 \%$, yang direndam selama 10 menit adalah $75 \%$, dengan tingkat penolakan $25 \%$, pada konsentrasi $15 \%$ yang direndam selama 5 menit adalah $87,5 \%$, tingkat penolakannya 2,5\%, yang direndam selama 10 menit adalah $72,5 \%$ dengan tingkat penolakannya $27,5 \%$.
Dari analisis sidik ragam pada Tabel 2, ternyata ulangan berpengaruh tidak nyata $(\mathrm{P}>0,05), \quad$ sedangkan konsentrasi berpengaruh nyata $(\mathrm{P}<0,05)$, kemudian lama perendaman berpengaruh tidak nyata $(\mathrm{P}>0,05)$, dan interaksi antara konsentrasi dan lama perendaman berpengaruh tidak nyata $(\mathrm{P}>0,05)$ terhadap perubahan warna daging yang direndam di dalam air perasan daun pegagan pada berbagai tingkat konsentrasi dan lama perendaman.

Tabel 1. Hasil uji organoleptik pengaruh konsentrasi dan lama perendaman air perasan daun pegagan terhadap kualitas daging babi.

\begin{tabular}{|c|c|c|c|c|c|c|c|c|c|c|c|c|c|}
\hline \multirow{3}{*}{ Daging } & \multirow{3}{*}{ Uji } & \multicolumn{8}{|c|}{ Ulangan (\%) } & \multicolumn{2}{|c|}{ Total (\%) } & \multicolumn{2}{|c|}{ Rata-rata $(\%)$} \\
\hline & & \multicolumn{2}{|c|}{1} & \multicolumn{2}{|c|}{2} & \multicolumn{2}{|c|}{3} & \multicolumn{2}{|c|}{4} & \multirow{2}{*}{$\mathrm{P} 1$} & \multirow[b]{2}{*}{$\mathrm{P} 2$} & \multirow[b]{2}{*}{ P1 } & \multirow[b]{2}{*}{$\mathrm{P} 2$} \\
\hline & & $\mathrm{P} 1$ & $\mathrm{P} 2$ & $\mathrm{P} 1$ & $\mathrm{P} 2$ & $\mathrm{P} 1$ & $\mathrm{P} 2$ & $\mathrm{P} 1$ & $\mathrm{P} 2$ & & & & \\
\hline \multirow{3}{*}{$\begin{array}{c}1 . \\
\text { Kons. } \% \% \\
5 \text { menit }\end{array}$} & $\mathrm{W}$ & 90 & 10 & 80 & 20 & 80 & 20 & 90 & 10 & 340 & 60 & 85 & 15 \\
\hline & B & 100 & 0 & 100 & 0 & 80 & 20 & 90 & 10 & 370 & 30 & 92,5 & 7,5 \\
\hline & $\mathrm{K}$ & 100 & 0 & 100 & 0 & 100 & 0 & 100 & 0 & 400 & 0 & 100 & 0 \\
\hline \multirow{3}{*}{\begin{tabular}{l}
\multicolumn{2}{c}{2.} \\
Kons.0\% 10 \\
menit
\end{tabular}} & $\mathrm{W}$ & 90 & 10 & 80 & 20 & 100 & 0 & 100 & 0 & 370 & 30 & 92,5 & 7,5 \\
\hline & $\mathrm{B}$ & 100 & 0 & 90 & 10 & 100 & 0 & 100 & 0 & 390 & 10 & 97,5 & 2,5 \\
\hline & $\mathrm{K}$ & 100 & 0 & 100 & 0 & 100 & 0 & 90 & 10 & 390 & 10 & 97,5 & 2,5 \\
\hline \multirow{3}{*}{\begin{tabular}{l}
\multicolumn{1}{c}{3.} \\
Kons. $5 \%$ \\
5 menit
\end{tabular}} & $\mathrm{W}$ & 70 & 30 & 50 & 50 & 100 & 0 & 50 & 50 & 270 & 130 & 67,5 & 32,5 \\
\hline & B & 80 & 20 & 100 & 0 & 90 & 10 & 90 & 10 & 360 & 40 & 90 & 10 \\
\hline & $\mathrm{K}$ & 90 & 10 & 100 & 0 & 70 & 30 & 100 & 0 & 360 & 40 & 90 & 10 \\
\hline \multirow{3}{*}{$\begin{array}{c}4 . \\
\text { Kons. } 5 \% \\
10 \text { menit }\end{array}$} & $\mathrm{W}$ & 60 & 40 & 90 & 10 & 90 & 10 & 100 & 0 & 340 & 60 & 85 & 15 \\
\hline & B & 80 & 20 & 70 & 30 & 90 & 10 & 80 & 20 & 320 & 80 & 80 & 20 \\
\hline & $\mathrm{K}$ & 100 & 0 & 100 & 0 & 90 & 10 & 100 & 0 & 390 & 10 & 97,5 & 12,5 \\
\hline \multirow{3}{*}{\begin{tabular}{l}
\multicolumn{1}{c}{5} \\
Kons. $10 \%$ \\
5 menit
\end{tabular}} & $\mathrm{W}$ & 90 & 10 & 80 & 20 & 90 & 10 & 10 & 90 & 270 & 130 & 67,5 & 32,5 \\
\hline & B & 80 & 20 & 100 & 0 & 90 & 10 & 60 & 40 & 330 & 170 & 82,5 & 17,5 \\
\hline & $\mathrm{K}$ & 100 & 0 & 100 & 0 & 90 & 10 & 80 & 20 & 370 & 30 & 92,5 & 7,5 \\
\hline \multirow{3}{*}{\begin{tabular}{l}
\multicolumn{1}{c}{6} \\
Kons. $10 \%$ \\
10 menit
\end{tabular}} & $\mathrm{W}$ & 30 & 70 & 30 & 70 & 90 & 10 & 50 & 50 & 200 & 200 & 50 & 50 \\
\hline & B & 60 & 40 & 80 & 20 & 60 & 40 & 60 & 40 & 260 & 140 & 65 & 35 \\
\hline & $\mathrm{K}$ & 70 & 30 & 80 & 20 & 50 & 50 & 100 & 0 & 300 & 100 & 75 & 25 \\
\hline \multirow{3}{*}{\begin{tabular}{l}
\multicolumn{1}{c}{7} \\
Kons. $15 \%$ \\
5 menit
\end{tabular}} & W & 70 & 30 & 100 & 0 & 60 & 40 & 50 & 50 & 280 & 120 & 70 & 30 \\
\hline & B & 80 & 20 & 100 & 0 & 60 & 40 & 70 & 30 & 310 & 90 & 77,5 & 22,5 \\
\hline & $\mathrm{K}$ & 80 & 20 & 100 & 0 & 80 & 20 & 90 & 10 & 350 & 50 & 87,5 & 12,5 \\
\hline \multirow{3}{*}{\begin{tabular}{l}
\multicolumn{1}{c}{8} \\
Kons. $15 \%$ \\
10 menit
\end{tabular}} & W & 30 & 70 & 30 & 70 & 80 & 20 & 20 & 80 & 160 & 240 & 40 & 60 \\
\hline & B & 50 & 50 & 80 & 20 & 70 & 30 & 60 & 40 & 260 & 140 & 65 & 35 \\
\hline & $\mathrm{K}$ & 80 & 20 & 80 & 20 & 70 & 30 & 60 & 40 & 290 & 110 & 72,5 & 27,5 \\
\hline
\end{tabular}

(Keterangan: $\mathrm{W}=$ Warna, $\mathrm{B}=\mathrm{Bau}, \mathrm{K}=$ Konsistensi, $\mathrm{P} 1=$ Tingkat penerimaan, $\mathrm{P} 2$ = Tingkat penolakan) 


\section{Uji sidik ragam}

Tabel 2. Hasil uji sidik ragam variabel warna, bau dan konsistensi daging yang direndam di dalam ekstrak daun pegagan pada berbagai konsentrasi dan lama perendaman.

\begin{tabular}{lccc}
\hline \multirow{2}{*}{ Sumber } & Warna & Bau & Konsistensi \\
\cline { 2 - 4 } & \multicolumn{3}{c}{ Signifikansi } \\
\hline Ulangan & 0,141 & 0,085 & 0,077 \\
Konsentrasi & 0,041 & 0,001 & 0,004 \\
Lama Perendaman & 0,363 & 0,032 & 0,065 \\
Interaksi Konsentrasi dan & 0,100 & 0,214 & 0,071 \\
Lama Perendaman & & &
\end{tabular}

Keterangan: $*=$ Berpengaruh nyata $(\mathrm{P}<0,05) ; \mathrm{TN}=$ Berpengaruh Tidak Nyata $(\mathrm{P}>0,05)$

Untuk perubahan bau daging dari analisis sidik ragam pada Tabel 2 ternyata ulangan berpengaruh tidak nyata $(\mathrm{P}>0,05)$, sedangkan konsentrasi berpengaruh nyata $(\mathrm{P}<0,05)$, lama perendaman berpengaruh nyata $(\mathrm{P}<0,05)$, dan interaksi antara konsentrasi dan lama perendaman berpengaruh tidak nyata $(\mathrm{P}>0,05)$, sedangkan untuk perubahan konsistensi dari analisis sidik ragam pada Tabel 2, ternyata ulangan berpengaruh tidak nyata $(\mathrm{P}>0,05), \quad$ sedangkan konsentrasi berpengaruh nyata $(\mathrm{P}<0,05)$, lama perendaman berpengaruh tidak nyata $(\mathrm{P}>0,05)$, dan interaksi antara konsentrasi dan lama perendaman berpengaruh tidak nyata $(\mathrm{P}>0,05)$ terhadap perubahan konsistensi daging yang direndam di dalam air perasan daun pegagan pada berbagai tingkat konsentrasi dan lama perendaman.

Perubahan warna daging dapat terjadi akibat reaksi pigmen dengan beberapa bahan (Cornforth et al., 1998; Mancini dan Hunt, 2005), dalam hal ini kemampuan pigmen daging untuk mengikat molekul lain tergantung pada status kimiawi ion besi yang terdapat pada cincin heme, jika ion ferro $(\mathrm{Fe} 2+)$ dioksidai menjadi ion ferri $(\mathrm{Fe} 3+)$, maka ion besi ini akan sulit untuk mengikat molekul lain, termasuk molekul oksigen. Jika ion ferro $(\mathrm{Fe} 2+)$ direduksi, maka ion ini akan mudah sekali bersatu dengan air seperti terjadi pada daging yang belum disayat atau jika bersatu dengan oksigen akan terlihat seperti daging yang sudah berhubungan dengan udara dalam beberapa saat (Mancini dan Hunt, 2005; Suardana dan Swacita, 2008; Sembiring et al., 2015). Pada penelitian ini kemungkinan yang terjadi adalah ion ferro $(\mathrm{Fe} 2+)$ daging yang direndam dalam air perasan daun pegagan direduksi kemudian berikatan dengan air perasan daun pegagan yang berwarna hijau, sehingga warna daging tersebut pun berubah menjadi kehijauan.

Bau dan rasa daging tergantung dari adanya prekursor yang terlarut dalam air dan lemak, serta pembebasan senyawa volatil dengan senyawa flavor yang spesifik (Suardana dan Swacita, 2008; Merthayasa et al., 2015). Jadi, bau daging babi yang direndam di dalam air perasan daun pegagan, maka dapat mempengaruhi bau daging babi tersebut menjadi agak berbau seperti daun pegagan. Dari Tabel 1 diatas dapat dilihat rata-rata terjadi penurunan persentase penerimaan panelis dari konsentrasi $0 \%$ dan lama perendaman 5 menit sampai konsentrasi $15 \%$ dan lama perendaman 10 menit, yang mengindikasikan terjadi penyimpangan bau daging dari normal menjadi agak berbau daun pegagan.

Warna dan tekstur daging dapat dipengaruhi oleh daya ikat air (Water Holding Capacity), dimana jika komponen air yang masih tertinggal yaitu air yang terikat erat dan air tidak bergerak akan menentukan daya ikat air daging (water holding capacity) tersebut (Suardana dan Swacita, 2008; Agustina et al., 2017b). Dalam hal ini, daya ikat air daging babi 
yang direndam di dalam air perasan daun pegagan pada berbagai konsentrasi dan lama perendaman akan lebih tinggi daripada daging yang tidak direndam, karena terendam di dalam cairan campuran air perasan daun pegagan dan akuades, sehingga warna dan tekstur dapat dipertahankan.

\section{SIMPULAN DAN SARAN}

\section{Simpulan}

Dapat disimpulkan bahwa konsentrasi berpengaruh terhadap perubahan warna, bau dan konsistensi daging babi, yang dalam hal ini terjadi penurunan kualitas warna, bau dan konsistensi daging yg menyimpang dari normal. Terjadi juga penurunan kualitas bau daging yang menyimpang dari normal yang dipengaruhi oleh lama perendaman, namun lama perendaman tidak mempengaruhi penurunan kualitas warna dan konsistensi daging dan tidak terdapat interaksi antara konsentrasi dan lama perendaman.

\section{Saran}

Pemberian air perasan daun pegagan disarankan untuk daging yang akan disimpan karena dapat menurunkan cemaran bakteri sehingga daging bisa disimpan lebih lama, sedangkan jika daging akan langsung diolah maka tidak disarankan untuk menggunakan air perasan daun pegagan karena akan terjadi perubahan warna, bau, dan konsistensi.

\section{UCAPAN TERIMAKASIH}

Penulis mengucapkan terimakasih kepada Laboratorium Kesmavet Fakultas Kedokteran Hewan Universitas Udayana, serta semua pihak yang telah membantu dalam proses penelitian ini.

\section{DAFTAR PUSTAKA}

Agfadila T, Sandhi PA, Puspawati NN. 2017. Kemampuan daya hambat ekstrak daun pegagan (Centella asiatica (L.) Urban) terhadap pertumbuhan
Escherichia coli ATCC 8739. J. ITEPA, 6(2): 21-29.

Agustina KK, Wirata IW, Dharmayudha AAGO, Kardena IM, Dharmawan NS. 2016. Increasing farmer income by improved pig management systems. Buletin Vet. Udayana, 8(2): 122-127.

Agustina KK, Sari PH, Suada IK. 2017a. Pengaruh perendaman pada infusa daun salam terhadap kualitas dan daya tahan daging babi. Buletin Vet. Udayana, 9(1): 34-41.

Agustina KK, Cahya IMRD, Widyantara GM, Swacita IBN, Dharmayudha AAGO, Rudyanto MD. 2017b. Nilai gizi dan kualitas fisik daging sapi bali berdasarkan jenis kelamin dan umur. Buletin Vet. Udayana, 9(2): 156-163.

Arka IB. 1990. Kualitas Daging Sapi Bali. Seminar Nasional Sapi Bali. 20-23 September 1990. Fakultas Peternakan Universitas Udayana. Denpasar.

Azzahra F, Hayati M. 2018. Uji aktivitas ekstrak daun pegagan (Centella asiatica (L). urb) terhadap pertumbuhan Streptococcus mutans. J. B-Dent., 5(1): 9-19.

Bermawie N, Purwiyanti S, Mardiana. 2008. Keragaman sifat morfologi, hasil dan mutu plasma nutfah pegagan (Centella asiatica (L.) Urban.). Bul. Littro. 14(1): 1-17.

Budaarsa K, Tirta KA, Budiasa KM, Astawa PA. 2013. Eksplorasi hijauan pakan babi dan cara penggunaannya pada peternakan babi tradisional di Provinsi Bali. Majalah Ilmiah Peternakan. 4(1): 26-30.

Cornforth DP, Rabovitser JK, Ahuja S, Wagner JC, Hanson R, Cummings B, Chudnovsky Y. 1998. Carbon monoxide, nitric oxide, and nitrogen dioxide levels in gas ovens related to surface pinking of cooked beef and turkey. J. Agric. Food Chem., 46: 255261.

Dash BK, Faruquee HM, Biswas SK, Alam MK, Sisir SM, Prodhan UK. 2011. Antibacterial and antifungal activities 
of several extracts of Centella asiatica $L$. against some human pathogenic microbes. Life Sci. Med. Res., 2011(35): $1-5$.

Jagtap NS, Khadabadi SS, Ghorpade DS, Banarase NB, Naphade SS. 2009. Antimicrobial and antifungal activity of centella asiatica (L.) urban, umbeliferae. Res. J. Pharm. Tech. 2(2): 328-330.

James JT. 2009. Pentacilin triterpenoid from the medicinal herb, Centella asiatica (L) urban. Molecules, 14: 3922-3941.

Mancini RA, Hunt MC. 2005. Current research in meat color. Meat Sci., 71(2005): 100-121.

Merthayasa JD, Suada IK, Agustina KK. 2015. Daya ikat air, pH, warna, bau dan tekstur daging sapi bali dan daging wagyu. Indonesia Med. Vet., 4(1): 1624.

Nowshad F, Islam MN, Khan MS. 2018. Concentration and formation behavior of naturally occurring formaldehyde in foods. Agric. Food Secur., 7(17): 1-8.
Nurrosyidah IH, Hermawati R, Asri M. 2019. Uji aktivitas antibakteri sediaan gel ekstrak etanol pegagan (Centela asiatica L.) terhadap bakteri Staphylococcus aureus secara in vitro. J. Pharm. Care Anwar Med., 2(1): 1-10. Sembiring UR, Suada IK, Agustina KK. 2015. Kualitas daging kambing yang disimpan pada suhu ruang ditinjau dari uji subjektif dan objektif. Indonesia Med. Vet., 4(2): 155-162.

Suada IK, Purnama DID, Agustina KK. 2018. Infusa daun salam mempertahankan kualitas dan daya tahan daging sapi bali. Buletin Vet. Udayana, 10(1): 100-109.

Suardana IW, Swacita IBN. 2008. Buku Ajar Higiene Makanan. Edisi I, Cetakan I. Udayana Press. Denpasar.

Sutardi. 2016. Kandungan bahan aktif tankandungan bahan aktif tanaman pegagan dan khasiatnya untuk meningkatkan sistem imun tubuhaman pegagan dan khasiatnya untuk meningkatkan sistem imun tubuh. $J$. Penelitian Pengembangan Pertanian, 35(3): 121-130. 